\section{Omega-3- og omega-6-tilskudd til premature?}

\author{
Tilskudd av omega-3- og omega-6-fettsyrer til premature barn etter \\ fødselen hadde ingen sikker langtidseffekt på kognitive evner eller \\ hjernevolum da barna var blitt åtte år. Dette viser en norsk studie.
}

Premature barn med fødselsvekt under $1500 \mathrm{~g}$ har økt risiko for svakere intellektuelle evner og strukturendringer i hjernen. De langkjedede fettsyrene omega-3 og omega-6 er essensielle for normal vekst av hjernen, og premature går glipp av den akkumuleringen de skulle ha hatt i slutten av svangerskapet. Forskere ved Akershus universitetssykehus har sett på langtidseffektene av tilskudd med omega-3 og omega- 6 på kognitive evner og hjernevolum (1).

Optimal ernæring er viktig for hjernens utvikling. Tidligere studier har vist at både mer næring og tilskudd av disse fettsyrene til premature barn har en positiv effekt på kognitive evner. MR-undersøkelse kan brukes til å påvise reduksjon av hjernevolum, og i flere studier er det vist sammenheng mellom MR-funn og intellektuelle evner.

I en norsk studie ble 129 premature barn med fødselsvekt under $1500 \mathrm{~g}$ rekruttert. Disse ble randomisert til å få enten tilskudd av omega-3 og omega-6 eller placebo i gjennomsnitt ni uker etter fødselen. Gruppen som fikk omega-3 og omega- 6 viste signifikant bedre oppmerksomhet ved seks og 20 måneders alder.

- Etter åtte år gjorde vi en oppfølgingsstudie av disse barna. Da så vi ikke lenger signifikante effekter av intervensjonen, verken på MR-undersøkelse eller i kognitive tester. Barna i begge grupper hadde ved åtte års alder lavere IQ og mindre hjernevolum enn barn født til termin, sier Astrid Nylander Almaas, som er barnelege og ph.d.-kandidat ved Akershus universitetssykehus.

- Vårt mål med denne oppfølgingsstudien var å undersøke om man fortsatt ville se effekter av tilskudd med fettsyrene omega-3 og omega-6 på hjernevolum og kognitiv funksjon når barna var blitt åtte år gamle. Det legges for tiden stor vekt på å minimere nevrokognitiv sekvele hos premature barn, og ernæringen er en av mange faktorer som påvirker hjernens utvikling. Vår studie er et bidrag i jakten på å forbedre prognosen for premature barn, sier hun.

- Studien er den første langtidsoppfølgingen etter intervensjon med omega- 3 og omega-6 med endepunktene cerebral MR og kognitive evner. Intervensjonen var begrenset og ligger langt tilbake i tid. Dette kan være en av årsakene til manglende effekt ved åtte års alder. Norske premature får også rutinemessig morsmelk, slik at begge gruppene i vår studie var sikret noe av

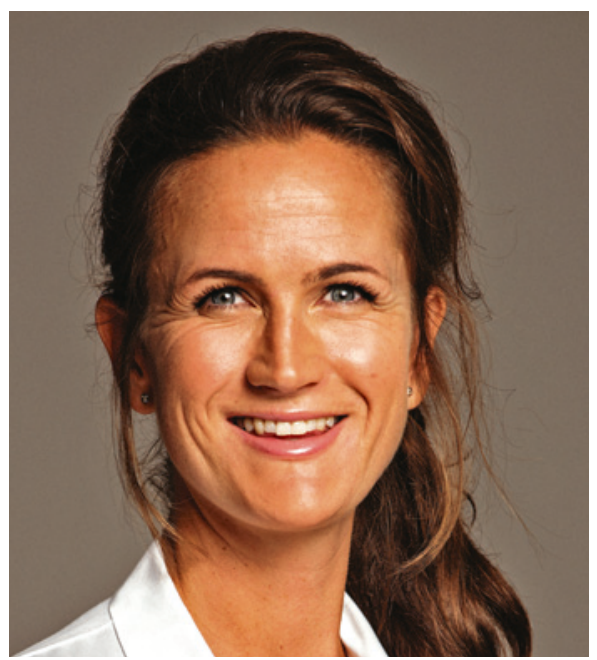

Astrid Nylander Almaas, studiens førsteforfatter. Foto: Kai M. Myhre

dette essensielle fettet. Langkjedede fettsyrer, inkludert omega-3 og omega-6, har dokumentert effekt på flere andre kliniske områder og er fortsatt et trygt og anbefalt tilskudd til premature barn, presiserer Almaas.

\section{Tverrfaglig forskergruppe}

Foruten Astrid Nylander Almaas har Britt

Nakstad, som er forskningsansvarlig ved Barne- og ungdomsklinikken ved Akershus universitetssykehus, bidratt til studien, i samarbeid med Per Ole Iversen, Christian A. Drevon og Christine Henriksen ved Institutt for klinisk ernæring, Universitetet i Oslo. Kognitive tester og MR-undersøkelser var planlagt og ble gjennomført i samarbeid med Kristine B. Walhovd, ved Psykologisk institutt ved Universitetet i Oslo. MR-undersøkelsene ble utført ved Radiologisk avdeling ved Oslo universitetssykehus, i samarbeid med overlege Paulina Due-Tønnesen.

\section{Kaveh Halland Rashidi}

Tidsskriftet

\section{Litteratur}

1. Almaas AN, Tamnes CK, Nakstad B et al. Longchain polyunsaturated fatty acids and cognition in VLBW infants at 8 years: an RCT. Pediatrics 2015; 135: 972-80. Anders Fjell og Christian Krog Tamnes
Ordforklaringer

Nevrokognitive funksjoner: Kognitive funksjoner knyttet opp mot spesifikke områder eller baner i hjernen.

Essensielle fettsyrer: Livsnødvendige fettsyrer som må tilføres gjennom kosten, siden kroppen ikke kan produsere disse selv.

Prematurt barn: Et barn født før svangerskapsuke 37.

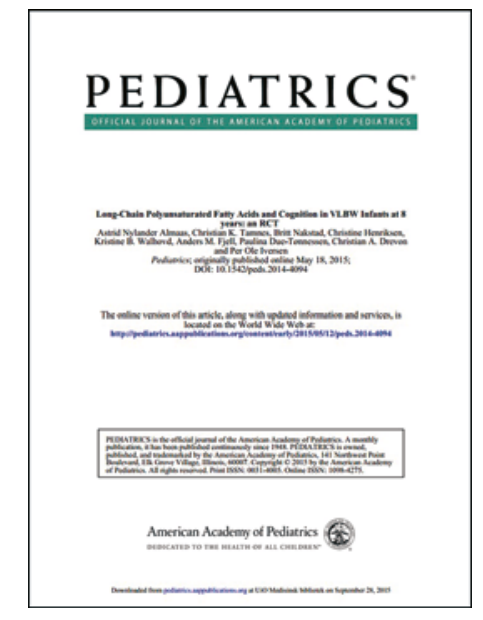

Studien ble publisert i Pediatrics i mai 2015 